\title{
ANALISIS PELAKSANAAN PUTUSAN PERADILAN AGAMA TERHADAP NAFKAH PERCERAIAN DALAM PRESPEKTIF HUKUM NASIONAL DAN HUKUM ISLAM BAGI PNS
}

\author{
Rendra Widyakso ${ }^{1}$, Fifik Wiryani2 ${ }^{*}$ \\ ${ }^{1,2}$ Magister Ilmu Hukum, Universitas Muhammadiyah Malang, Indonesia \\ *fwiryani2016@gmail.com (corresponding).
}

\begin{abstract}
Decisions can be executed if, a court decision contains an order for one of the parties to pay a sum of money or vacate a permanent object. Usually, divorce cases that occur will punish the husband to make a payment of some money as a living for the divorced wife after the Religious Court Judge decides. The penalty is in the form of giving 1/3 (one third) of the salary given to the ex-wife and 1/3 (one third) of the others assigned to his child. Based on Government Regulation No. 10 of 1983 jo Government Regulation No. 45 of 1990, the penalty applies to husbands who work as Civil Servants (PNS). In some case adoption of decisions, often not going well even not implemented. Therefore, many respondents demanded the Petitioner to provide several divorce wages, such as mut' ah payments for livelihoods, iddah income, and Ahmadiyah livelihoods, which were carried out before the promise of divorce was pronounced and had to make a living. For sacrifice after the execution of the divorce agreement is canceled. The Panel of Judges will grant such a request, but this request is not for civil servants. So, the authors conducted research using the juridical-normative method to examine the source of law in the Regulations stated in the Religious Court decision. The results obtained that the panel of judges in their decision view that the regulation is only an administrative requirement in each government agency.
\end{abstract}

Keywords: Divorce; Income; Judgment.

\section{PENDAhuluan}

Perkawinan dalam Kamus Besar Bahasa Indonesia diartikan sebagai ikatan (akad) perkawinan yang dilakukan sesuai dengan ajaran dan ketentuan hukum dan agama (Disemadi, AlFatih, \& Yusro, 2020; Purwadarminta, 2008). Bagi yang beragama Islam diatur khusus dalam Kompilasi Hukum Islam berbunyi bahwa Perkawinan menurut Hukum Islam adalah pernikahan yaitu akad yang sangat kuat atau mitssaqan ghalidzan untuk mentaati perintah Allah dan melaksanakannya merupakan ibadah. Setiap pasangan suami istri tentunya mendambakan agar 86 | Article History, Submitted 7 May 2021 - Revision Required 16 May 2021 - Accepted 27 May 2021. 
keluarga yang dibina dapat berjalan secara harmonis dan selalu diridhoi oleh Tuhan Yang Maha Esa. Guna menjadi keluarga yang kekal, harmonis, dan bahagia harus sesuai dengan hak asasi manusia tanpa adanya unsur paksaan dari pihak manapun dalam mencapai keluarga yang bahagia. Namun demikian banyak juga keluarga yang gagal dalam mengupayakan keharmonisannya dan berujung pada perceraian. Adapun hasil analisa dikutip dari jurnal ilmu pemerintahan dan sosial politik UMA bahwa faktor perceraian mendasar pada empat hal yakni karena faktor ekonomi, faktor usia, kurang pengetahuan agama, dan ketidak sesuaian pendapat dalam rumah tangga (Matondang, 2014).

Di Indonesia menurut data umum statistik tentang Pegawai Negeri Sipil, jumlahnya mencapai 4.286.918 per 30 Juni 2019 (BKN, 2019). Dalam perkawinan dan perceraian bagi Pegawai Negeri Sipil diatur dalam Peraturan Pemerintah Nomor 45 Tahun 1990 tentang Perubahan Atas Peraturan Pemerintah Nomor 10 Tahun 1983 tentang Izin Pekawinan dan Perceraian Bagi Pegawai Negeri Sipil. Khususnya bagi PNS yang akan bercerai harus mendapatkan izin dari atasan. Kewajiban tersebut berlaku bagi Pegawai Negeri Sipil yang akan melakukan perceraian, baik sebagai Penggugat/Pemohon dan Tergugat/Termohon. Perizinan tersebut akan memiliki konsekuensi hukum atas perceraian yang dilakukan oleh Pegawai Negeri Sipil, konseuensi yang didapat yakni pembagian 1/3 gaji yang diberikan kepada mantan isterinya, 1/3 bagian untuk anaknya, dan 1/3 untuk dirinya sebagaimana diatur pada Pasal 8 Peraturan Pemerintah Nomor 10 Tahun 1983, namun dalam praktinya izin dari atasan hanya menjadi syarat administratif dalam mengajukan perkara perceraian di Pengadilan dan tidak berdampak pada putusan atas pembagian gaji sebagaimana diatur dalam Pasal tersebut (Al-Thofina, 2018). Dalam hal ini berarti bahwa mantan suami memiliki kewajiban untuk menyerahkan $1 / 3$ bagian gajinya mulai dari putusan disahkan hingga sang istri menikah lagi. Tentunya hal ini bertentangan dengan Hukum Islam, yang mana di anggap sebagai pembebanan nafkah secara khusus. Hukum Islam mengatur dalam perkara cerai talak sebagaimana dijelaskan dalam Pasal 149 Kompilasi, seorang suami yang telah mentalak istrinya diwajibkan untuk memberikan nafkah mut'ah, nafkah iddah, melunasi mahar yang masih terhutang, dan memberikan biaya hadhanah.

Sedangkan dalam perkara cerai gugat diperkenankan bagi isteri (Penggugat) mengajukan tuntutan nafkah perceraian sebagaimana hasil pleno kamar agama yang dituangkan dalam Surat Edaran Mahkamah Agung No. 3 Tahun 2018. Islam tidak mengatur batasan waktu pemberian nafkah perceraian (Annas, 2017). Hanya saja berdasarkan ijtihad bahwa nafkah iddah hanya diberikan selama 3 (tiga) kali selama masa suci mantan isteri, dan nafkah madiyah (terutang) diberikan sejak mantan suami tidak menafkahinya. Pernyatan ini berbeda dengan Pemerintah Nomor 10 Tahun 1983 sehingga muncul perbedaan pendapat antara Hakim tentang penggunaan Peraturan Pemerintah tersebut. Hal ini dikarenakan tidak sesuai dengan Hukum Islam dan teori kemaslahatan. Oleh karena itu, penulis berusaha untuk menggali pertimbangan Majelis Hakim Peradilan Agama dalam memutus perkara perceraian dengan konsekuensi pembebanan nafkah perceraian bagi Pegawai Negeri Sipil.

Penelitian terdahulu menunjukan bahwa kewenangan mengadili perkara perihal nafkah pasca perceraian, bukan hanya menjadi kompetensi absolut dari Pengadilan Agama (Fadri, Mukhlis, \& 
Yusrizal, 2020) dan Pengadilan Negeri (Mantili \& Lubis, 2017), melainkan juga Pengadilan Tata Usaha Negara (Fadri et al., 2020). Perihal nafkah, hukum Islam pada dasarnya tidak mengenal adanya konsep harta bersama sehingga nafkah seharusnya ditanggung hanya oleh salah satu pihak, namun menjadi berbeda saat ditinjau dari prespektif Kompilasi Hukum Islam (Nelli, 2017).

Namun, hingga saat ini, belum terdapat penelitian yang membahas perihal bagaimana konsep pembebanan nafkah perceraian dalam pandangan Hukum Nasional dan Hukum Islam; dan bagaimana penerapan Pasal 8 Peraturan Pemerintah.No.. 45 Tahun 1990 tentang Perubahan. Atas Peraturan Pemerintah No. 10 Tahun 1983 tentang Izin Pekawinan dan Perceraiann bagi Pegawai Negeri Sipil dalam pertimbangan Majelis Hakim. Kontribusi penelitian ini diharapkan dapat menjawab permasalahan masyarakat terutama yang berstatus PNS maupun pasangannya perihal pembenanan nafkah perceraian dan penerapannya di Indonesia.

\section{METODE PENELITIAN}

Penelitian ini adalah penelitian hukum normatif (Peter Mahmud Marzuki, 2017). Penelitian berjenis kualititaf, merupakan penelitian yang dilakukan oleh seseorang dengan sasaran penelitian yang terbatas, walaupun sasaran penelitian ini terbatas, tetapi data yang digali sangat mendalam dan berkualitas. Analisis isi (content analysis) pada penelitian kualitatif lebih penting daripada symbol atau atribut seperti pada penelitian kuantitatif (Irwansyah, 2020). Penelitian kualitatif memerlukan ketajaman analisis, objektifitas, dan sistematis, sehingga diperoleh ketepatan dalam interpretasi. Sebab hakikat dari suatu fenomena atau gejala bagi penganut penelitian kualitatif adalah totalitas atau gestalt (Zuriah, 2009). Penelitian ini juga menggunakan pendekatan yuridisnormatif, merupakan suatu cara yang digunakan dalam suatu penelitian yang menggunakan asasasas, serta peraturan perundang-undangan guna meninjau, melihat serta menganalisa permasalahan.

Jenis data yang digunakan dalam penelitian ini adalah data primer yaitu data undang-undang yang diperoleh dari Peradilan Agama di Semarang. Selain itu penelitian ini menggunakan data sekunder meliputi buku, artikel, makalah, jurnal hukum Islam, majalah, koran online dan lain sebagainya Selain itu penelitian ini juga melakukan penelitian lapang (field research), hal itu dikarenakan data yang diperoleh dari studi pustaka kurang cukup. Penelitian ini menggunakan teknik pengumpulan data berupa, membaca literatur yang berkaitan (Library Research), selain itu peneltian ini juga menggunakan teknik (Field Research), yaitu mengamati dan mengumpulkan data secara langsung dari lapangan, dengan menggunakan proses iterview dan dokumentasi lapangan.

\section{HASIL DAN PEMBAHASAN}

\section{Konsep Pembebanan Nafkah Perceraian Dalam Pandangan Hukum Islam dan Hukum Positif}

\section{Nafkah Perceraian Dalam Pandangan Hukum Islam}

Nafkah secara bahasa berasal dari kata nafaqa yang artinya belanja atau biaya. Secara terminologis, nafkah diartikan sebagai sesuatu yang mencukupi, berupa makanan, pakaian, dan tempat tinggal bagi yang menanggungnya. Nafkah merupakan suatu hal yang wajib dipenuhi oleh 
seorang suami terhadap isteri dan anak-anaknya. Sebagaimana dijelaskan dalam QS At-Thalaq ayat 7 yang artinya "Hendaklah orang yang mampu memberi nafkah menurut kemampuannya. dan orang yang disempitkan rezkinya hendaklah memberi nafkah dari harta yang diberikan Allah kepadanya. Allah tidak memikulkan beban kepada seseorang melainkan sekedar apa yang Allah berikan kepadanya. Allah kelak akan memberikan kelapangan sesudah kesempitan."

Maksud daripada ayat tersebut menegaskan bahwa seorang suami memiliki kewajiban dalam memberi nafkah atau pembelanjaaan untuk isteri dan anak-anaknya sesuai dengan kemampuannya. Namun dalam hal ini tidak ada ketentuan berapa besar kewajiban seorang suami dalam memberikan nafkah kepada isteri dan anak-anaknya. Adapun menurut beberapa ulama' mendefenisikan tentang nafkah sebagai berikut:

a. Para fuqoha mendefenisikan nafkah sebagai biaya yang wajib hukumnya dikeluarkan oleh seseorang terhadap sesuatu yang berada dalam tanggungannya meliputi sandang, pangan, dan papan termasuk kebutuhan sekunder seperti kebutuhan rumah tangga lainnya;

b. Adapun menurut al-Sayid Sabiq dalam bukunya nafkah didefenisikan sebagai kebutuhan makan, tempat tinggal, pembantu rumah tangga, pengobatan istri, bagi seseorang yang kaya (Syuhada, 2013).

Berdasarkan dari definisi dan pandangan para ulama' dapat disimpulkan bahwa defenisi nafkah adalah sesuatu yang dibelanjakan oleh seseorang untuk dirinya sendiri atau untuk orang lain dalam hal ini keluarga yakni isteri dan anak baik berupa makanan, minuman, pakaian, perumahan, dan kebutuhan lainnya. Sehingga nafkah tersebut merupakan suatu hal yang mempunyai nilai manfaat atau nilai materi yang diberikan oleh suami kepada isteri dan anak-anaknya.

Secara Hukum Islam, nafkah diatur dalam Al-Qur'an QS Al-Baqarah ayat 233 yang artinya:

Para ibu hendaklah menyusukan anak-anaknya selama dua tahun penuh, Yaitu bagi yang ingin menyempurnakan penyusuan. dan kewajiban ayah memberi Makan dan pakaian kepada Para ibu dengan cara ma'ruf. seseorang tidak dibebani melainkan menurut kadar kesanggupannya. janganlah seorang ibu menderita kesengsaraan karena anaknya dan seorang ayah karena anaknya, dan warispun berkewajiban demikian. apabila keduanya ingin menyapih (sebelum dua tahun) dengan kerelaan keduanya dan permusyawaratan, Maka tidak ada dosa atas keduanya. dan jika kamu ingin anakmu disusukan oleh orang lain, Maka tidak ada dosa bagimu apabila kamu memberikan pembayaran menurut yang patut. Bertakwalah kamu kepada Allah dan ketahuilah bahwa Allah Maha melihat apa yang kamu kerjakan.

Dari ayat di atas dapat diketahui bahwa ada bentuk kewajiban nafkah yang hanya diberikan kepada yang berhak, seorang suami terhadap isterinya. Dalam hal ini memberikan sesuatu tersebut berdasarkan dengan kebutuhan bukan menentukan jumlah nafkah yang harus diberikan. Tidak diatur sedemikian rupa, dikarenakan adanya kekhawatiran terjadinya pemborosan penggunaan dalam suatu keadaan tertentu. 
Adapun dalam suatu riwayat Hadist yang diriwayatkan oleh Ahmad, Abu Daud, Nasa'i, dan Ibnu Majah menyebutkan bahwa:

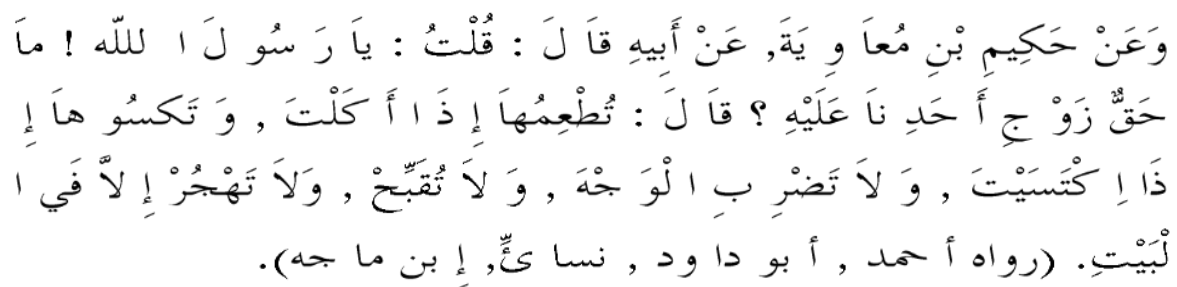

Artinya: Dari Hakim bin Muawiyah, dari ayahnya dia berkata, "Aku bertanya, Wahai Rosulullah, apakah kewajiban kami terhadap istrinya? Beliau menjawab, "Engkau memberikannya makan jika engkau makan, engkau memberinya pakaian jika engkau berpakaian, jangan memikul muka,jangan menjelek-jelekan, dan jangan berpisah (dari tempa tidurnya), kecuali didalam rumah. (HR. Ahmad, Abu Daud, Nasa ${ }^{e e} I$, Ibnu Majah)(Mardani, 2012).

Hadist yang diriwayatkan oleh Ahmad, Abu Daud, Nasa'i, dan Ibnu Majah menerangkan bahwa nafkah yang harus diberikan oleh suami kepada isterinya berupa:

a. Memberi nafkah baik berupa sandang, pangan, dan papan;

b. Tidak menyakiti isteri;

c. Memberikan nafkah batin.

Para fuqoha sepakat berpendapat bahwa memberikan nafkah kepada isteri dan anak-anaknya hukumnya wajib, kecuali seorang isteri tersbeut telah melakukan nusyuz. Ulama' Fikih juga sependapat bahwa nafkah yang harus dikeluarkan adalah berupa kebutuhan pokok seperti makan, pakaian, dan tempat tinggal. Para ulama' fikih membagi nafkah atas dua macam yakni:

a. Nafkah untuk dirinya sendiri;

Dianjurkan seseorang tersebut untuk mendahulukan nafkah untuk dirinya sendiri daripada nafkah kepada orang lain, sebagaimana Hadist yang disabdakan oleh Rasullullah SAW sebagai berikut:

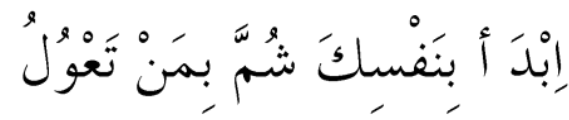

Artinya: "Mulailah dengan dirimu, kemudian bagi orang yang berada dibawah tanggungjawabmu" (HR. Muslim, Ahmad bin Hambal, Abu Daud, dan An Nasa'i dari Jabir bin Abdullah)(Saebani, 2001).

b. Nafkah seseorang terhadap orang lain

Ulama fiqih sepakat bahwa ada dua hal yang menyebabkan terjadinya kewajiban memberikan nafkah, yakni (Dahlan, 2009):

a. Hubungan perkawinan; 
Diwajibkan bagi seorang suami memberi nafkah kepada isterinya yang tidak nusyuz baik berupa makanan, pakaian, tempat tinggal, dan lainnya menurut keadaan dan ditempat masing-masing menurut kemampuan suami.

b. Hubungan kekerabatan;

Hubungan kekeluargaan yaitu bapak atau ibu dan yang masih memiliki hubungan kerabat lainnya.

Berkaitan dengan nafkah, Islam tidak hanya mengatur kewajiban memberikan nafkah kepada isteri dan anak-anaknya yang masih dalam perkawinan, namun Islam juga mengatur hal-hal yang wajib bagi seorang mantan suami memberikan nafkah kepada isteri dan anak-anaknya pasca perceraian. Hal ini mendasar pada Q.S At-Thalaq ayat 7 yang artinya: hendaklah orang yang mampu memberi nafkah menurut kemampuannya. dan orang yang disempitkan rezkinya hendaklah memberi nafkah dari harta yang diberikan Allah kepadanya. Allah tidak memikulkan beban kepada seseorang melainkan sekedar apa yang Allah berikan kepadanya. Allah kelak akan memberikan kelapangan sesudah kesempitan.

Dalam Hadits disebutkan:

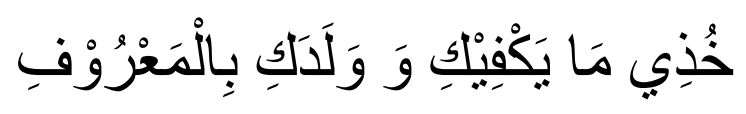

Artinya: "Ambillah (dari harta suamimu) apa yang mencukupimu dan anak-anakmu dengan cara yang baik".

Sehingga dari kedua dasar hukum yang diterangkan dalam Al-Qur'an maupun Hadits menjadi konsekuensi kewajiban bagi suami untuk menafkahi istri dan anak-anaknya. Mengingat bahwa selama masih menjadi suami istri yang sah menurut hukum dan agama hukumnya wajib menafkahi. Adapun dengan anak bahwa dari berbagai pandangan manapun tidak memutus hubungan darah antara anak dengan orang tuanya jika terjadi perceraian.

Perceraian kerap terjadi khususnya di Indonesia yang mana dari segi pihak yang mengajukan dapat diklasifikasian menjadi dua macam, yakni cerai talak dan cerai gugat.

a. Cerai talak didefinisikan dalam Pasal 114 KHI bahwa:

Putusnya perkawinan yang disebabkan karena perceraian dapat terjadi karena talak atau berdasarkan gugatan perceraian" lebih lanjut dijelaskan dalam Pasal $129 \mathrm{KHI}$ yang berbunyi: "seseorang suami yang akan menjatuhkan talak kepada istrinya mengajukan permohonan baik lisan maupun tertulis kepada Pengadilan Agama yang mewilayahi tempat tinggal istri dengan alasan serta meminta agar diadakan sidang untuk keperluan itu.

b. Cerai Gugat didefinisikan dalam Pasal 132 ayat 2 KHI yang berbunyi: "Gugatan perceraian diajukan oleh isteri atau kuasanya pada Pengadilan Agama yang daerah hukumnya mewilayahi tempat tinggal Penggugat kecuali istri meninggalkan tempat kediaman tanpa izin suami” 
Adanya dua klasifikasi jenis perkara perceraian yang dapat diajukan di Pengadilan Agama memiliki konsekuensi masing-masing. Khususnya terhadap konsekuensi pembebanan nafkah terhadap perkara perceraian.

Adapun nafkah perceraian yang diatur dalam Hukum Islam adalah sebagai berikut:

a. Nafkah Iddah

Agama Islam mengatur tentang nafkah pasca perceraian atau disebut dengan nafkah iddah berdasarkan pada ayat Al-Qur'an dan hadist sebagaimana berikut dalam Surah Q.S AtThalaq ayat 1 yang artinya "Hai Nabi, apabila kamu menceraikan isteri-isterimu maka hendaklah kamu ceraikan mereka pada waktu mereka dapat (menghadapi) iddahnya (yang wajar) dan hitunglah waktu iddah itu serta bertakwalah kepada Allah Tuhanmu. Janganlah kamu keluarkan mereka dari rumah mereka dan janganlah mereka (diizinkan) ke luar kecuali mereka mengerjakan perbuatan keji yang terang. Itulah hukum-hukum Allah, maka sesungguhnya dia telah berbuat zalim terhadap dirinya sendiri. Kamu tidak mengetahui barangkali Allah mengadakan sesudah itu sesuatu hal yang baru". Selain itu dijelaskan dalam Q.S At-Thalaq ayat: 6 yang Artinya: "Tempatkanlah mereka (para isteri) di mana kamu bertempat tinggal menurut kemampuanmu dan janganlah kamu menyusahkan mereka untuk menyempitkan (hati) mereka. dan jika mereka (isteri-isteri yang sudah ditalaq) itu sedang hamil, maka berikanlah kepada mereka nafkahnya hingga mereka bersalin, kemudian jika mereka menyusukan (anak-anak)mu untukmu maka berikanlah kepada mereka upahnya, dan musyawarahkanlah di antara kamu (segala sesuatu) dengan baik; dan jika kamu menemui kesulitan maka perempuan lain boleh menyusukan (anak itu) untuknya.

Dalam Hadist riwayat An-Nasa'i disebutkan “Dari Fatimah bib Qays, ia berkata: “Aku menemui Nabi SAW, dan menjelaskan bahwa aku adalah anak dari keluarga Khalid. Suamiku, si Fulan, mengutus seseorang kepadaku untuk menyampaikan talaknya. Aku menuntut kepada keluarganya hakku terhadap nafkah dan tempat tinggal. Mereka mengabulkannya. Mereka menjelaskan kepada Rasulullah bahwa "Suaminya telah menyampaikan talak sebanyak tiga kali" Fathimah berkata lagi Rasulullah SAW bersabda: "Hak nafkah dan tempat tinggal hanya dimiliki oleh seorang perempuan apabila suaminya masih memiliki hak rujuk kepadanya." (H.R An -Nasa'i) (Al-Baihaqi, 1994; Al-Daruquthni, 1966; Al-Nasa i, 1986).

Maka berdasarkan ayat Qur'an dan Hadist di atas para ulama sepakat mengatakan bahwa bagi perempuan yang dijatuhi talak raj'i memiliki hak untuk memperoleh nafkah iddah dan tempat tinggal. Adapun dalam kitab Wahbah Al-Zuhaili Figh Al-Islam wa Adillatuh terhadap perempuan yang dijatuhi talak $b a^{\prime}$ in para ulama sepakat apabila perempuan tersebut dalam keadaan hamil, maka dia berhak mendapatkan nafkah dan tempat tinggal (Al-Malikiy, n.d.; Al-Zuhaili, 1998).

Sedangkan bagi perempuan-perempuan yang dijatuhkan talak $b a$ 'in tetapi tidak dalam kondisi hamil maka terdapat pendapat yang berbeda bagi para ulama, yakni:

1) Pendapat Ulama Syafi'iyah dan Malikiyah (Anas, 1994); 
Berpendapat bahwa perempuan yang dijatuhkan talak $b a$ 'in dalam keadaan tidak hamil, haknya hanya mendapatkan tempat tinggal dan tidak mendapatkan hak nafkah. Tempat tinggal yang dimaksud mengacu pada ayat 6 surat At-Thalaq pada kalimat askinuhunna (berikanlah mereka tempat tinggal). Sedangkan dengan tidak dapatnya nafkah dikaitkan dengan kondisinya yang tidak sedang hamil maka tidak ada kewajiban atas nafkah tersebut.

2) Pendapat Ulama Hanabilah (Qudamah, 1997) dan Zhahiriyah;

Keduanya berpendapat bahwa tidak berhak mendapatkan nafkah dan tempat tinggal. Dasar dari pendapat ini adalah hadist yang diriwayatkan oleh An-Nasa' $i$ di atas yang mengatakan bahwa Fatimah binti Qais telah ditalak tiga kali oleh suaminya. Lalu Rasulullah SAW bersabda kepada Fatimah engkau tidak ada hak nafkah dari suaminya. Pendapat ini juga merupakan pendapat dari Ibnu Abbas, Jabis bin Abdillah, sebagian Tabi'imn dan Ishaq (Zuhaili, 2008).

3) Pendapat Ulama Hanafiyah (Kasany, 2010)

Ulama Hanafiyah berpendapat bahwa istri yang dijatuhi talak $b a$ 'in tetap memiliki hak atas nafkah dan maskan (tempat tinggal) seperti perempuan yang dijatuhi talak raj'i berdasarkan ayat 6 dari surat At-Thalaq. Menurut beliau bahwa esensi yang terkandung dalam ayat tersebut adanya perintah tentang wajibnya memberikan tempat tinggal yaitu pada kalimat askinuhunna (berikanlah mereka tempat tinggal) dan isteri yang ditalak $b a$ 'in tersebut wajib menghabiskan masa iddah di rumah suaminya. Hal ini dikarenakan suaminya masih ada hak kepadanya berupa kepastian ada atau tidaknya pembuahan dalam rahim sehingga dianggap wajar perempuan tersebut mendapatkkan haknya berupa nafkah. Adapun maksud nafkah dalam ayat tersebut yang dikaitkan dengan kehamilan, dikarenakan iddah hamil adalah iddah yang paling lama sehingga perlu ditegaskan sedangkan untuk masa iddah yang lebih pendek dari itu telah tercakup di dalamnya. Sehingga nafkah tersebut dianggap hutang yang resmi sejak dijatuhkannya talak dan tidak dapat dihapuskan kecuali sudah dibayarkan (Sabiq, 1998).

b. Nafkah Mut'ah

Tafsir as-Sabuni mengartikan bahwa nafkah dimaknai sebagai Mut'ah, yang artinya pemberian seorang suami kepada isterinya yang telah diceraikan, baik berupa uang, pakaian, atau berupa pembekalan lainnya sebagai bantuan dan bentuk penghormatan kepada isterinya sehingga dapat menghindarkan kemudharatan talak yang dijatuhkannya. Selain itu, makna daripada mut'ah diartikan sebagai penghibur, namun dalam hal ini harus disesuaikan dengan kemampuannaya sebagaiman yang dijelaskan dalam firman Allah SWT Q.S Al-Baqarah ayat 241 yang artinya: "Kepada wanita-wanita yang diceraikan (hendaklah diberikan oleh suaminya) mut'ah menurut yang ma'ruf, sebagai suatu kewajiban bagi orang-orang yang bertakwa." 
Menurut ayat tersebut, Mut'ah (pemberian) diartikan sebagai sesuatu yang diberikan oleh suami kepada isteri yang diceraikannya sebagai penghibur, selain nafkah sesuai dengan kemampuannya. Intinya ayat tersebut merupakan perwujudan mendapatkan persesuaian kepada Hukum Islam bahwa dalam hal ini nafkah setelah nafkah iddah tersebut telah habis. Tujuan pemberian Mut'ah seorang suami terhadap isteri yang telah diceraikannya adalah dengan adanya pemberian tersebut diharapkan dapat menghibur atau menyenangkan hati isterinya tersebut. Selain itu untuk membersihkan hati dan fikiran kaum wanita dan menghilangkan kekhawatiran terhadap penghinaan kaum pria terhadapnya (Ghazaly, 2003).

Keharusan memberi mut'ah, yaitu pemberian suami kepada istri yang diceraikannya sebagai suatu konpensasi. Hal ini berbeda dengan mut'ah sebagai pengganti mahar bila istri di cerai sebelum digauli dan sebelumnya jumlah mahar tidak ditentukan, tidak wajib suami memberi mahar, namun diimbangi dengan suatu pemberian yang bernama mut'ah. Dalam kewajiban memberi mut'ah itu terdapat perbedaan pendapat di kalangan ulama, golongan zhahiriyah berpendapat bahwa mut'ah itu hukumnya wajib. Dasarnya ialah firman Allah dalam surat al-Baqarah ayat 241, yang artinya: "Kepada wanita-wanita yang diceraikan (hendaklah diberikan oleh suaminya) mut'ah menurut yang ma`ruf, sebagai suatu kewajiban bagi orang-orang yang takwa."

Ulama Malikiyah berpendapat bahwa mut'ah itu hukumnya sunnah, karena kalimat haqqan 'ala al-muttaqin di ujung ayat tersebut menunjukkan hukumnya adalah tidak wajib, kewajiban mut'ah itu berlaku dalam keadaan tertentu.

c. Melunasi utang yang wajib dibayarnya dan belum dibayarnya selama masa perkawinan, baik dalam bentuk mahar atau nafkah, yang menurut sebagian ulama wajib dilakukannya bila ada waktunya dia tidak dapat membayarnya. Begitu pula mahar yang belum dibayar atau dilunasinya, harus dilunasinya setelah bercerai.

d. Pemeliharaan terhadap anak atau hadhanah.

\section{Nafkah Perceraian Dalam Pandangan Hukum Positif}

Hukum positif juga mengatur tentang nafkah pasca perceraian. Sebelum adanya Kompilasi Hukum Islam yang dituangkan dalam Instruksi Presiden No. 1 Tahun 1991, Undang-Undang No. 1 Tahun 1974 tentang Perkawinan telah menjelaskan dalam Bab VIII Putusnya Perkawinan Serta Akibatnya. Dalam Pasal 41 menjelaskan bahwa akibat putusnya perkawinan karena perceraian ialah:

a. Baik ibu atau bapak tetap berkewajiban memelihara dan mendidik anak-anaknya, semata-mata berdasarkan kepentingan anak, bilamana ada perselisihan mengenai penguasaan anak-anak, Pengadilan memberi keputusan;

b. Bapak yang bertanggung jawab atas semua biaya pemeliharaan dan pendidikan yang diperlukan anak itu, bilamana bapak dalam kenyataannya tidak dapat memberi kewajiban tersebut pengadilan dapat menentukan bahwa ibu ikut memikul biaya tersebut; 
c. Pengadilan dapat mewajibkan kepada bekas suami untuk memberikan biaya penghidupan dan/atau menentukan sesuatu kewajiban bagi bekas isteri;

Merujuk pada pasal tersebut dalam Undang-Undang No. 1 Tahun 1974 tentang Perkawinan menjelaskan bahwa akibat putusnya perkawinan mengatur tentang kewajiban dan tanggungjawab bapak atau ibu dari anak atau anak-anaknya dalam memberikan pemeliharaan, pendidikan, dan kasih sayang semata-mata berdasarkan atas kepentingan anak. Berkaitan dengan biaya dalam hal ini menjadi tanggungjawab keduanya, meskipun bilamana ada perselisihan maka Pengadilan berhak untuk menentukan kepada siapa kewajiban tersebut diberikan. Dan dalam huruf c pasal tersebut menyatakan bahwa Pengadilan dapat mewajibkan kepada bekas suami untuk memberikan biaya penghidupan dan/atau menentukan sesuatu kewajiban bagi bekas isteri.

Adapun dalam Pasal 149 Kompilasi Hukum Islam mengatur bahwa "Bilamana perkawinan putus karena cerai talak maka bekas suami wajib:

a. memberikan mut'ah yang layak kepada bekas isterinya, baik berupa uang atau benda, kecuali bekas isteri tersebut qobla al dukhul;

b. memberi nafkah, maskan dan kiswah kepada bekas isteri selama dalam iddah, kecuali bekas isteri telah di jatuhi talak $b a$ 'in atau nusyus dan dalam keadaan tidak hamil;

c. melunasi mahar yang masih terhutang seluruhnya, dan separoh apabila qobla al dukhul;

d. memeberikan biaya hadhanah untuk anak-anaknya yang belum mencapai umur 21 tahun.

Berbeda dengan aturan bagi Pegawai Negeri Sipil yang bercerai sebagaimana diatur dalam Peraturan Pemerintah Nomor 45 Tahun 1990 tantang Perubahan Atas Peraturan Pemerintah Nomor 10 Tahun 1983 tentang Izin Perkawinan dan Perceraian Bagi Pegawai Negeri Sipil yang mana sebelum mengajukan perkara perceraian di Pengadilan, maka syaratnya bagi suami atau isteri yang bekerja sebagai Pegawai Negeri Sipil baik kedudukannya sebagai Penggugat atau Tergugat harus mendapatkan izin atasan. Sebagaimana disebutkan dalam Pasal 3 ayat (1) dan ayat (2) Peraturan Pemerintah Nomor 45 Tahun 1990 tentang Perubahan Atas Peraturan Pemerintah Nomor 10 Tahun 1983 tentang Izin Pekawinan dan Perceraian Bagi Pegawai Negeri Sipil yang bunyinya:

a. Pegawai Negeri Sipil yang akan melakukan perceraian wajib memperoleh izin atau surat keterangan lebih dahulu dari pejabat;

b. Bagi Pegawai Negeri Sipil yang berkedudukan sebagai Penggugat atau bagi Pegawai Negeri Sipil yang berkedudukan sebagai Tergugat untuk memperoleh izin atau surat keterangan sebagaimana dimaksud dalam ayat (1) harus mengajukan permintaan secara tertulis;

Tidak hanya mengatur tentang syarat administrasi berupa izin atasan, dalam Peraturan Pemerintah Nomor 45 Tahun 1990 tentang Perubahan Atas Peraturan Pemerintah Nomor 10 Tahun 1983 tentang Izin Pekawinan dan Perceraian Bagi Pegawai Negeri Sipil juga mengatur tentang kewajiban yang harus dilaksanakan oleh Pegawai Negeri Sipil pria pasca putusnya perkawinannya oleh Pengadilan. Dalam hal ini disebutkan di dalam Pasal 8 Peraturan Pemerintah Nomor 45 Tahun 
1990 tentang Perubahan Atas Peraturan Pemerintah Nomor 10 Tahun 1983 tentang Izin Pekawinan dan Perceraian Bagi Pegawai Negeri Sipil menyebutkan:

a. Apabila perceraian terjadi atas kehendak Pegawai Negeri Sipil pria maka ia wajib menyerahkan sebagian gajinya untuk penghidupan bekas isteri dan anak-anaknya;

b. Pembagian gaji sebagaimana dimaksud dalam ayat (1) ialah sepertiga untuk Pegawai Negeri Sipil pria yang bersangkutan, sepertiga untuk bekas isterinya, dan sepertiga untuk anak atau anak-anaknya;

c. Apabila dari perkawinan tersebut tidak ada anak maka bagian gaji yang wajib diserahkan oleh Pegawai Negeri Sipil pria kepada bekas isterinya ialah setengah dari gajinya;

d. Pembagian gaji kepada bekas istri tidak diberikan apabila alasan perceraian disebabkan karena istri berzinah, dan atau melakukan kekejaman atau penganiayaan berat baik lahir maupun batin terhadap suami, dan atau istri menjadi pemabuk, pemadat, dan penjudi yang sukar disembuhkan, dan atau istri telah meninggalkan suami selama dua tahun berturut-turut tanpa izin suami dan tanpa alasan yang sah atau karena hal lain diluar kemampuannya;

e. Apabila perceraian terjadi atas kehendak isteri, maka ia tidak berhak atas bagian penghasilan dari bekas suaminya;

f. Ketentuan sebagaimana dimaksud dalam ayat (5) tidak berlaku, apabila istri minta cerai karena dimadu, dan atau suami berzinah, dan atau suami melakukan kekejaman atau penganiayaan berat baik lahir maupun batin terhadap istri, dan atau suami menjadi pemabuk, pemadat, dan penjudi yang sukar disembuhkan, dan atau suami telah meninggalkan istri selama dua tahun berturut-turut tanpa izin istri dan tanpa alasan yang sah atau karena hal lain diluar kemampuannya;

g. Apabila bekas isteri Pegawai Negeri Sipil yang bersangkutan kawin lagi, maka haknya atas bagian gaji dari bekas suaminya menjadi hapus terhitung mulai ia kawin lagi;

Dari ketiga dasar hukum positif tersebut terdapat hal-hal yang membedakan diantaranya:

a. Dalam Undang-Undang Nomor 1 Tahun 1974 tentang Perkawinan berlaku bagi setiap orang yang beragama non-Muslim dan melangsungkan perkawinannya sesuai dengan kepercayaannya. Sedangkan Kompilasi Hukum Islam berlaku bagi setiap orang yang beragama Islam dan perkawinannya sesuai dengan ajaran Islam. Dalam Peraturan Pemerintah Nomor 45 Tahun 1990 tentang Perubahan Atas Peraturan Pemerintah Nomor 10 Tahun 1983 tentang Izin Pekawinan dan Perceraian Bagi Pegawai Negeri Sipil berlaku bagi siapa saja yang menikah baik menggunakan ajaran Islam maupun menurut kepercayaan lainnya;

b. Khususnya dalam perceraian, Undang-Undang Nomor 1 Tahun 1974 tentang Perkawinan dan Kompilasi Hukum Islam tidak mengatur tentang syarat administratif berupa izin atasan, sehingga setiap orang yang bekerja baik swasta maupun Pegawai Negeri Sipil tidak diwajibkan untuk memperoleh izin atasan. Namun hal ini bagi Pegawai Negeri Sipil secara khusus diatur dalam Peraturan Pemerintah Nomor 45 Tahun 1990 tentang Perubahan Atas Peraturan Pemerintah Nomor 10 Tahun 1983 tentang Izin Pekawinan dan Perceraian Bagi Pegawai Negeri Sipil wajib memperoleh izin atasan sebagaimana dijelaskan dalam Pasal 6 nya; 
c. Dalam hal kewajiban bagi setiap orang yang telah bercerai memiliki kewajiban yang harus dipenuhi pasca putusnya perkawinan. Undang-Undang Nomor 1 Tahun 1974 tentang Perkawinan sebagaimana disebutkan dalam Pasal 41 bahwa:

Ibu atau bapak tetap berkewajiban memelihara dan mendidik anak-anaknya, sematamata berdasarkan kepentingan anak, Bapak yang bertanggung jawab atas semua biaya pemeliharaan dan pendidikan yang diperlukan anak itu, bilamana bapak dalam kenyataannya tidak dapat memberi kewajiban tersebut pengadilan dapat menentukan bahwa ibu ikut memikul biaya tersebut; dan Pengadilan dapat mewajibkan kepada bekas suami untuk memberikan biaya penghidupan dan/atau menentukan sesuatu kewajiban bagi bekas isteri.

Sedangkan dalam Pasal 149 Kompilasi Hukum Islam memiliki beberapa macam bentuk nafkah yang diberikan oleh mantan suami kepada mantan isterinya berupa nafkah mut'ah, nafkah iddah, maskan, kiswah, melunasi mahar yang masih terutang, dan biaya hadhanah. Dalam Pasal 8 Peraturan Pemerintah Nomor 45 Tahun 1990 tentang Perubahan Atas Peraturan Pemerintah Nomor 10 Tahun 1983 tentang Izin Pekawinan dan Perceraian Bagi Pegawai Negeri Sipil maka bagi lakilaki ada kewajiban untuk memberikan gajinya 1/3 untuk bekas isterinya, 1/3 untuk anak atau anakanaknya, dan $1 / 3$ untuk yang bersangkutan. Pembebanan nafkah perceraian tersebut akan terhenti apabila mantan isteri telah kawin lagi.

Dari ketiga perbedaan tersebut tentunya bagi yang bekerja sebagai Pegawai Negeri Sipil diatur secara khusus melalui Peraturan Pemerintah Nomor 45 Tahun 1990 tentang Perubahan Atas Peraturan Pemerintah Nomor 10 Tahun 1983 tentang Izin Pekawinan dan Perceraian Bagi Pegawai Negeri Sipil sehingga apabila tidak dilaksankan sesuai dengan ketentuan tersebut maka akan dikenakan sanksi sebagaimana dijelaskan dalam Pasal 16 yang bunyinya "Pegawai Negeri Sipil yang menolak melaksanakan ketentuan pembagian gaji sesuai dengan ketentuan Pasal 8, dijatuhi salah satu hukuman disiplin berat berdasarkan Peraturan Pemerintah Nomor 30 Tahun 1980 tentang Peraturan Disiplin Pegawai Negeri Sipil."

\section{Penerapan Isi Pasal 8 Peraturan Pemerintah Nomor 45 Tahun 1990 Tentang Perubahan Atas Peraturan Pemerintah Nomor 10 Tahun 1983 Tentang Izin Pekawinan Dan Perceraian Bagi Pegawai Negeri Sipil Dalam Pertimbangan Majelis Hakim}

\section{Konsekuensi Perceraian Bagi Pegawai Negeri Sipil Berdasarkan Peraturan Pemerintah Nomor 45 Tahun 1990 Tentang Perubahan Atas Peraturan Pemerintah Nomor 10 Tahun 1983 Tentang Izin Pekawinan Dan Perceraian Bagi Pegawai Negeri Sipil}

Perceraian merupakan pemutusan tali perkawinan antara suami dan isteri. Sebagaimana disebutkan dalam Pasal 207 KUHPerdata disebutkan bahwa: perceraian merupakan penghapusan perkawinan dengan putusan hakim, atas tuntutan salah satu pihak dalam perkawinan itu berdasarkan alasan-alasan yang tersebut dalam undang-undang. Menurut Subekti dalam bukunya perceraian ialah penghapusan perkawinan dengan putusan hakim, atau tuntutan salah satu pihak dalam perkawinan itu (Subekti, 1983). Sebagaimana disebutkan dalam Pasal 39 ayat (1) Undang- 
Undang Nomor 1 Tahun 1974 tentang Perkawinan berbunyi "Perceraian hanya dapat dilakukan di depan sidang pengadilan setelah Pengadilan yang bersangkutan berusaha dan tidak berhasil mendamaikan kedua belah pihak, mengingat sebagaimana berdasarkan Undang-Undang Nomor 7 Tahun 1989 tentang Pengadilan Agama bahwa salah satu kewenangannya mengadili perkara perceraian".

Pada umunya bagi pihak yang mendaftarkan perceraian di Pengadilan Agama harus memenuhi syarat setidaknya adalah gugatan atau permohonan dan fotokopi buku nikah yang telah dinazegelen di kantor Pos Indonesia. Berbeda dengan Pegawai Negeri Sipil yang secara admministratif harus melampirkan izin dari atasan sebagaimana dijelaskan dalam Pasal 3 Peraturan Pemerintah Nomor 45 Tahun 1990 tentang Perubahan Atas Peraturan Pemerintah Nomor 10 Tahun 1983 tentang Izin Pekawinan dan Perceraian Bagi Pegawai Negeri Sipil yang bunyinya:

a. Pegawai Negeri Sipil yang akan melakukan perceraian wajib memperoleh izin atau surat keterangan lebih dahulu dari pejabat;

b. Bagi Pegawai Negeri Sipil yang berkedudukan sebagai Penggugat atau bagi Pegawai Negeri Sipil yang berkedudukan sebagai Tergugat untuk memperoleh izin atau surat keterangan sebagaimana dimaksud dalam ayat (1) harus mengajukan permintaan secara tertulis;

c. Dalam surat permintaan izin atau pemberitahuan adanya gugatan perceraian untuk mendapatkan surat keterangan, harus dicantumkan alasan yang lengkap dan mendasarinya;

Sehingga menjadi suatu kewajiban syarat yang harus dipenuhi baik bagi Penggugat/Pemohon dan Tergugat/Termohon untuk melampirkan izin atasan. Yang mana izin atasan tersebut harus dilampirkan secara tertulis dengan memuat alasan Pegawai Negeri Sipil tersebut dan pertimbangan atasan, sebagaimana dijelaskan dalam Pasal 5 ayat (2) Peraturan Pemerintah Nomor 45 Tahun 1990 tentang Perubahan Atas Peraturan Pemerintah Nomor 10 Tahun 1983 tentang Izin Pekawinan dan Perceraian Bagi Pegawai Negeri Sipil, bahwa:

Setiap atasan yang menerima permintaan izin Pegawai Negeri Sipil dalam lingkungannya, baik untuk melakukan perceraian atau untuk beristeri lebih dari seorang, maupun untuk menjadi isteri kedua/ketiga/keempat, wajib memberikan pertimbangan dan meneruskannya kepada Pejabat melalui saluran hierarki dalam jangka waktu selambat-lambatnya 3 (tiga) bulan terhitung mulai tanggal ia menerima permintaan izin dimaksud;

Pertimbangan atasan yang diberikan izin untuk melakukan perceraian sebagimana dijelaskan dalam Pasal 7 Peraturan Pemerintah Nomor 45 Tahun 1990 tentang Perubahan Atas Peraturan Pemerintah Nomor 10 Tahun 1983 tentang Izin Pekawinan dan Perceraian Bagi Pegawai Negeri Sipil adalah sebagai berikut:

a. Izin untuk bercerai dapat diberikan oleh Pejabat apabila didasarkan pada alasan-alasan yang ditetapkan oleh peraturan perundang-undangan dan ketentuan-ketentuan dalam Peraturan Pemerintah ini;

b. Izin untuk bercerai karena alasan isteri mendapat cacat badan atau penyakit dengan akibat tidak dapat menjalankan kewajibannya sebagai isteri, tidak diberikan oleh Pejabat; 
c. Izin untuk bercerai tidak diberikan oleh Pejabat apabila:

1) bertentangan dengan ajaran/peraturan agama yang dianut Pegawai Negeri Sipil yang bersangkutan;

2) tidak ada alasan sebagaimana dimaksud dalam ayat (1),

3) bertentangan dengan peraturan perundang-undangan yang berlaku; dan/atau

4) alasan yang dikemukakan bertentangan dengan akal sehat

Apabila berdasarkan alasan di atas, atasan merasa kurang yakin dengan pernyataannya Pegawai Negeri Sipil tersebut maka Pejabat diperbolehkan memintai keterangan tambahan dari suami/isteri dari Pegawai Negeri Sipil yang mengajukan permintaan izin atau dari pihak lain yang dipandang dapat memberikan keterangan yang menyakinkan.

Hal ini tidak menutup kemungkinan pelaksanaan atas asas mempersulit perceraian yang merupakan asas hukum yang terdapat dalam penjelasn umum Undang-Undang Nomor 1 Tahun 1974 tentang Perkawinan dalam angka 4 huruf e yang menyatakan bahwa pada prinsipnya UndangUndang Perkawinan ini menganut asas mempersulit perceraian yang memungkinkan terjadinya perceraian jika perceraian itu dilakukan dihadapan Pengadilan dan berdsarkan alasan-alasan tertentu. Adapun tujuannya tidak lain adalah mengutuhkan perkawinan untuk membentuk keluarga yang bahagia dan kekal (As'adi, 2012).

Dalam hal perkara perceraian tentunya memiliki konsekuensi hukum yang berlaku. Pada perkara cerai talak sebagaimana disebutkan dalam Pasal 140 KHI mewajibkan bekas suami untuk memberikan nafkah mut'ah, nafkah madiyah, nafkah iddah, dan nafkah anak. Dan untuk perkara cerai gugat sebagaimana SEMA Nomor 3 Tahun 2018 Hasil Pleno Kamar Agama dibolehkan tuntutan nafkah yang diajukan oleh Penggugat.

Untuk Pegawai Negeri Sipil juga memiliki konsekuensi hukum yang harus ditaati bagi yang akan melangsungkan perceraian. Hal ini diatur dalam Pasal 8 Peraturan Pemerintah Nomor 45 Tahun 1990 tentang Perubahan Atas Peraturan Pemerintah Nomor 10 Tahun 1983 tentang Izin Pekawinan dan Perceraian Bagi Pegawai Negeri Sipil bahwa:

a. Apabila perceraian terjadi atas kehendak Pegawai Negeri Sipil pria maka ia wajib menyerahkan sebagian gajinya untuk penghidupan bekas isteri dan anak-anaknya;

b. Pembagian gaji sebagaimana dimaksud dalam ayat (1) ialah sepertiga untuk Pegawai Negeri Sipil pria yang bersangkutan, sepertiga untuk bekas isterinya, dan sepertiga untuk anak atau anak-anaknya;

c. Apabila dari perkawinan tersebut tidak ada anak maka bagian gaji yang wajib diserahkan oleh Pegawai Negeri Sipil pria kepada bekas isterinya ialah setengah dari gajinya;

d. Pembagian gaji kepada bekas istri tidak diberikan apabila alasan perceraian disebabkan karena istri berzinah, dan atau melakukan kekejaman atau penganiayaan berat baik lahir maupun batin terhadap suami, dan atau istri menjadi pemabuk, pemadat, dan penjudi yang sukar disembuhkan, dan atau istri telah meninggalkan 
suami selama dua tahun berturut-turut tanpa izin suami dan tanpa alasan yang sah atau karena hal lain diluar kemampuannya;

e. Apabila perceraian terjadi atas kehendak isteri, maka ia tidak berhak atas bagian penghasilan dari bekas suaminya;

f. Ketentuan sebagaimana dimaksud dalam ayat (5) tidak berlaku, apabila istri minta cerai karena dimadu, dan atau suami berzinah, dan atau suami melakukan kekejaman atau penganiayaan berat baik lahir maupun batin terhadap istri, dan atau suami menjadi pemabuk, pemadat, dan penjudi yang sukar disembuhkan, dan atau suami telah meninggalkan istri selama dua tahun berturut-turut tanpa izin istri dan tanpa alasan yang sah atau karena hal lain diluar kemampuannya;

g. Apabila bekas isteri Pegawai Negeri Sipil yang bersangkutan kawin lagi, maka haknya atas bagian gaji dari bekas suaminya menjadi hapus terhitung mulai ia kawin lagi.

Dari Peraturan Pemerintah di atas bagi Pegawai Negeri Sipil sebagai Pemohon dalam perkara Cerai Talak yang beragama Islam tidak hanya secara khusus memiliki kewajiban untuk memberikan nafkah mut'ah, nafkah madiyah, nafkah iddah, dan nafkah anak saja, tetapi sebagaimana ayat (6) Peraturan Pemerintah di atas wajib menafkahi hingga bekas istri Pegawai Negeri Sipil tersebut kawin lagi. Yang dengan tujuan tidak membiarkan anak dan mantan istrinya dengan tanpa nafkah sampai dengan menikah lagi bersama laki-laki yang kemudian akan bertanggungjwab kepada dirinya.

Konsekuensi tersebut tentunya menjadi suatu hal yang harus dilakukan oleh Pegawai Negeri Sipil pria yang akan telah bercerai. Namun sebelum semua itu dilaksanakan oleh pejabat yang berwenang, sesuai dengan Pasal 15 Peraturan Pemerintah Nomor 45 Tahun 1990 tentang Perubahan Atas Peraturan Pemerintah Nomor 10 Tahun 1983 tentang Izin Pekawinan dan Perceraian Bagi Pegawai Negeri Sipil yang bunyinya:

a. Pegawai Negeri Sipil yang melanggar salah satu atau lebih kewajiban/ketentuan Pasal 2 ayat (1),ayat (2),Pasal 3 ayat (1), Pasal 4 ayat (1),Pasal 14,tidak melaporkan perceraiannya dalam jangka waktu selambat-lambatnya satu bulan terhitung mulai terjadinya perceraian, dan tidak melaporkan perkawinannya yang kedua/ketiga/keempat dalam jangka waktu selambat-lambatnya satu tahun terhitung sejak perkawinan tersebut dilangsungkan, dijatuhi salah satu hukuman disiplin berat berdasarkan Peraturan Pemerintah Nomor 30 Tahun 1980 tentang Peraturan Disiplin Pegawai Negeri Sipil;

b. Pegawai Negeri Sipil wanita yang melanggar ketentuan Pasal 4 ayat (2), dijatuhi hukuman disiplin pemberhentian tidak dengan hormat sebagai Pegawai Negeri Sipil;

c. Atasan yang melanggar ketentuan Pasal 5 ayat 2 dan Pejabat yang melanggar ketentuan Pasal 12, dijatuhi salah satu hukuman disiplin berat berdasarkan Peraturan Pemerintah Nomor 30 Tahun 1980 tentang Peraturan Disiplin Pegawai Negeri Sipil;

Bagi Pegawai Negeri Sipil yang menolak melaksanakan ketentuan pembagian gaji tersebut sesuai dengan Pasal 16 Pemerintah Nomor 45 Tahun 1990 tentang Perubahan Atas Peraturan Pemerintah Nomor 10 Tahun 1983 tentang Izin Pekawinan dan Perceraian Bagi Pegawai Negeri Sipil bahwa: "Pegawai Negeri Sipil yang menolak melaksanakan ketentuan pembagian gaji sesuai dengan ketentuan Pasal 8, dijatuhi salah satu hukuman disiplin berat berdasarkan Peraturan 
Pemerintah Nomor 30 Tahun 1980 tentang Peraturan Disiplin Pegawai Negeri Sipil”. Adapun yang dimaksud dijatuhi disiplin berat sebagaimana dalam Pasal 6 ayat (4) Peraturan Pemerintah Nomor 53 Tahun 2010 tentang Peraturan Disiplin Pegawai Negeri Sipil. Jenis hukuman disiplin berat terdiri dari:

a. Penurunan pangkat pada pangkat yang setingkat lebih rendah untuk paling lama 1 (satu) tahun;

b. Pembebasan dari jabatan;

c. Pemberhentian dengan hormat tidak atas permintaan sendiri sebagai pegawai Negeri Sipil; dan

d. Pemberhentian tidak dengan hormat sebagai Pegawai Negeri Sipil.

Namun, sejauh ini regulasi peraturan pemerintah ini belum dapat diterapkan secara maksimal. Terlebih pada Peraturan Pemerintah ini hanya berhenti pada izin atasan yang kemudian tidak memiliki dampak selain pemenuhan syarat administratif.

\section{Pertimbangan Majelis Hakim Dalam Memutus Perkara Perceraian Dengan Surat Izin Atasan Bagi Pegawai Negeri Sipil}

Pengambilan putusan oleh Majelis Hakim dalam pertimbangan hukum mengenal istilah ex officio menurut Kamus Hukum diartikan karena jabatan, seperti dalam kalimat memangku jabatan secara ex officio (Puspa, 1977). Sedangkan menurut subekti bahwa pengertian hak ex officio berasal dari Bahasa latin ambtshalve Bahasa Belanda yang berarti karena jabatan, tidak berdasarkan surat penetapan atau pengankatan, juga tidak berdasarkan suatu permohonan (Subekti \& Tjitrosoedibjo, 1979). Maka secara defenitif dimaknai suatu hak atau kewenangan yang dimiliki oleh Hakim karena jabatannya, dan salah satunya adalah untuk memutus atau memberikan sesuatu yang tidak ada dalam tuntutan.

Ex officio berdasarkan Pasal 178 HIR ayat (3) dan Pasal 189 RBg ayat (3) menyebutkan bahwa Hakim dilarang menjatuhkan putusan atas perkara yang tidak dituntut atau mengabulkan lebih yang dituntut (Soeroso, 2010). Namun khususnya dalam perkara perceraian diatur khusus bahwa Hakim diperbolehkan untuk mewajibkan sesuatu kepada mantan suami atau mantan isteri. Dengan tujuan menegakkan keadilan dan kemaslahatan sebagaimana hak ex officio diatur dalam Pasal 41 huruf c Undang-Undang Nomor 1 Tahun 1974 tentang Perkawinan yang bunyinya: "Pengadilan dapat mewajibkan kepada bekas suami untuk memberikan biaya penghidupan dan/atau menentukan suatu kewajiban bagi bekas isteri." Sehingga dari pasal ini dalam perkara perceraian menjadi landasan bagi Hakim untuk memutus di luar tuntutan.

Adanya dinamika dan perkembangan zaman yang semakin meningkat, maka tidak menutup kemungkinan hakim berwewenang melakukan contra legem apabila ketentuan suatu pasal undangundang bertentangan dengan kepatutan dan tidak sesuai dengan kenyataan dan keadaan yang berkembang dalam jiwa, perasaan dan kesadaran masyarakat (Hartini, 2009). Sebagaimana dalam perkara perceraian talak, secara hak ex officio pun tanpa ada gugatan rekonvensi dari isteri dapat 
menjatuhkan hukum bagi suami sebagai Pemohon untuk membayar nafkah. Termasuk Hakim sebagai penegak hukum dan keadilan wajib menggali, mengikuti, dan memahami nilai-nilai hukum yang hidup dalam masyarakat yang kemudian diterapkan dalam memeriksa dan memutus perkara yang kaitannya dengan agama menentukan suatu kewajiban yang melekat pada diri suami sebagai suatu akibat perbuatan hukum tertentu (Fauzan \& Noerfuady, 1997).

Selain memahami suatu konteks hak ex officio tentunya tidak terlepas dari pada teori kemaslahatan, seperti dijelaskan dalam firman Allah SWT dalam Q.S. Al-Anbiyya' ayat 107 yang artinya: Dan Tiadalah Kami mengutus kamu, melainkan untuk (menjadi) rahmat bagi semesta alam. Dari ayat tersebut di atas bahwa sesungguhnya hadirnya Hukum Islam sebagai rahmat bagi seluruh manusia dan alam, tidaklah terwujud kecuali jika benar-benar demi kemaslahatan dan kebaikan bagi manusia. Dalam kaidah fiqhiyyah disebutkan:

$$
\text { الضرر يدفع بقدر الإمكان }
$$

Artinya: Kemudharatan dihilangkan sekadar kemampuan

Dari kaidah di atas dapat diketahui bahwa adanya suatu kewajiban menghindarkan akan terjadinya suatu kemudharatan atau dengan kata lain bahwa usaha agar terjadinya suatu kemudharatan atau dengan kata lain bahwa usaha agar jangan sampai terjadi suatu kemudharatan dengan segala upaya yang mungkin untuk diusahakan. Yang kemudian dikutip dalam hadist Nabi yang bunyinya:

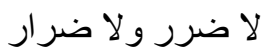

Artinya: Tidak ada Kemudharatan dan tidak memudharatkan

Terlebih dalam regulasi perundang-undangan sebagaimana diamanatkan dalam Peraturan Pemerintah Nomor 45 Tahun 1990 tentang Perubahan Atas Peraturan Pemerintah Nomor 10 Tahun 1983 tentang Izin Pekawinan dan Perceraian Bagi Pegawai Negeri Sipil maka suatu syarat administratif bagi Penggugat/Pemohon dan Tergugat/Termohon tidak hanya menjadi syarat tapi berdampak pada konsekuensi hukum yang dijelaskan dalam Pasal 8 Peraturan Pemerintah Nomor 45 Tahun 1990 tentang Perubahan Atas Peraturan Pemerintah Nomor 10 Tahun 1983 tentang Izin Pekawinan dan Perceraian Bagi Pegawai Negeri Sipil bahwa :

a. Apabila perceraian terjadi atas kehendak Pegawai Negeri Sipil pria maka ia wajib menyerahkan sebagian gajinya untuk penghidupan bekas isteri dan anak-anaknya;

b. Pembagian gaji sebagaimana dimaksud dalam ayat (1) ialah sepertiga untuk Pegawai Negeri Sipil pria yang bersangkutan, sepertiga untuk bekas isterinya, dan sepertiga untuk anak atau anak-anaknya;

c. Apabila dari perkawinan tersebut tidak ada anak maka bagian gaji yang wajib diserahkan oleh Pegawai Negeri Sipil pria kepada bekas isterinya ialah setengah dari gajinya;

d. Pembagian gaji kepada bekas istri tidak diberikan apabila alasan perceraian disebabkan karena istri berzinah, dan atau melakukan kekejaman atau penganiayaan berat baik lahir maupun batin terhadap suami, dan atau istri menjadi pemabuk, pemadat, dan penjudi yang sukar disembuhkan, dan atau istri telah meninggalkan 
suami selama dua tahun berturut-turut tanpa izin suami dan tanpa alasan yang sah atau karena hal lain diluar kemampuannya;

e. Apabila perceraian terjadi atas kehendak isteri, maka ia tidak berhak atas bagian penghasilan dari bekas suaminya;

f. Ketentuan sebagaimana dimaksud dalam ayat (5) tidak berlaku, apabila istri minta cerai karena dimadu, dan atau suami berzinah, dan atau suami melakukan kekejaman atau penganiayaan berat baik lahir maupun batin terhadap istri, dan atau suami menjadi pemabuk, pemadat, dan penjudi yang sukar disembuhkan, dan atau suami telah meninggalkan istri selama dua tahun berturut-turut tanpa izin istri dan tanpa alasan yang sah atau karena hal lain diluar kemampuannya;

g. Apabila bekas isteri Pegawai Negeri Sipil yang bersangkutan kawin lagi, maka haknya atas bagian gaji dari bekas suaminya menjadi hapus terhitung mulai ia kawin lagi;

Maka demikian sudah diatur dalam Peraturan Pemerintah tersebut, Majelis Hakim secara ex officio dibenarkan memutus suatu perkara khususnya cerai talak dengan mempertimbangkan kedudukannya sebagai Pegawai Negeri Sipil dan konsekuensi hukumnya.

Perlu diperhatikan bahwa dengan adanya Peraturan Pemerintah Nomor 45 Tahun 1990 tentang Perubahan Atas Peraturan Pemerintah Nomor 10 Tahun 1983 tentang Izin Pekawinan dan Perceraian Bagi Pegawai Negeri Sipil tentunya sebagai aturan khusus bagi Pegawai Negeri Sipil yang bercerai (lex spesialis derogate generalis) bukan kemudian tidak mengindahkan UndangUndang Nomor 1 Tahun 1974 tentang Perkawinan, Kompilasi Hukum Islam, dan Surat Edaran Mahkamah Agung Nomor 3 Tahun 2018 tentang Hasil Pleno Kamar sebagaimana pelaksana atas Peraturan Mahkamah Agung Nomor 3 Tahun 2017 tentang Pedoman Mengadili Perkara Perempuan Berhadapan dengan Hukum. Yang mana justru memberikan dampak positif bagi perlindungan hak-hak isteri. Pelaksanaan dalam perkara cerai talak sesuai dengan Pasal 140 Kompilasi Hukum Islam akibat talak bunyinya:

Bila perkawinan putus karena talak, maka bekas suami wajib:

a. Memberikan mut'ah yang layak kepada bekas isterinya, baik berupa uang atau benda, kecuali bekas isteri tersebut qobla al dukhul;

b. Memberi nafkah, maskan dan kiswah kepada bekas isteri selama dalam iddah, kecuali bekas isteri telahdi jatuhi talak balin atau nusyur dan dalam keadaan tidak hamil;

c. Melunasi mahar yang masih terhutang seluruhnya, dan separoh apabila qobla al dukhul;

d. Memberikan biaya hadhanan untuk anak-anaknya yang belum mencapai umur 21 tahun

Pasal tersebut tetap dilaksanakan secara konsekuensi hukum akibat talak. Namun disisi lain dengan adanya aturan khusus bagi laki-laki Pegawai Negeri Sipil yang mengajukan perkara perceraian, maka dibebani dengan aturan yang berlaku yang pada pokoknya:

a. Apabila ada anak maka pembagiannya adalah sepertiga untuk mantan isteri, sepertiga untuk anak, dan sepertiga bagian gajinya untuk dirinya; 
b. Apabila belum dikaruniai anak maka pembagiannya adal setengah bagian untuk mantan isteri dan setengah bagian gaji untuk dirinya;

Sedangkan dalam Pasal 8 ayat (7) Peraturan Pemerintah Nomor 45 Tahun 1990 tentang Perubahan Atas Peraturan Pemerintah Nomor 10 Tahun 1983 tentang Izin Pekawinan dan Perceraian Bagi Pegawai Negeri Sipil yang pada pokoknya hak mantan isteri atas bagian gaji dari bekas suaminya menjadi hapus terhitung mulai ia kawin lagi memang perlu dibatasi. Apabila mengacu pada Hukum Islam tentunya sesuai dengan masa iddah yakni selama tiga kali suci atau haid (quru'), sebagaimana dijelaskan dalam Q.S. Al-Baqarah ayat 228 yang artinya "Wanitawanita yang ditalak handaklah menahan diri (menunggu) tiga kali quru'. tidak boleh mereka Menyembunyikan apa yang diciptakan Allah dalam rahimnya, jika mereka beriman kepada Allah dan hari akhirat. dan suami-suaminya berhak merujukinya dalam masa menanti itu, jika mereka (para suami) menghendaki ishlah. dan Para wanita mempunyai hak yang seimbang dengan kewajibannya menurut cara yang ma'ruf. akan tetapi Para suami, mempunyai satu tingkatan kelebihan daripada isterinya. dan Allah Maha Perkasa lagi Maha Bijaksana”.

Maka bisa dinisbatkan sesuai dengan ajaran agama Islam, hanya saja dalam menetapkan besaran nafkahnya mengacu pada Peraturan Pemerintah Nomor 45 Tahun 1990 tentang Perubahan Atas Peraturan Pemerintah Nomor 10 Tahun 1983 tentang Izin Pekawinan dan Perceraian Bagi Pegawai Negeri Sipil, yakni sepertiga bagian jika memiliki anak dan seperdua bagian gaji apabila tidak dikaruniai anak. Sedangkan untuk nafkah yang diberikan kepada anak sesuai dengan ketentuan Kompilasi Hukum Islam bahwa anak wajib hukumnya diberikan nafkah hadhanah sampai usia 21 tahun.

\section{Pelaksanaan Putusan Hakim Dalam Penetapan Nafkah Terhadap Perceraian Yang Diajukan Oleh Pegawai Negeri Sipil}

Pelaksanaan putusan Hakim dalam penetapan Nafkah terhadap perceraian yang diajukan oleh Pegawai Negeri Sipil tentunya akan menimbulkan suatu polemik yang belum terjawab. Pada dasarnya yang diperiksa dan diadili oleh Majelis Hakim hanyalah para pihak yang tercantum dalam gugatan. Dalam permasalahan ini adanya izin atasan bagi Pegawai Negeri Sipil selain berdampak pada ketentuan yang telah diatur dalam Peraturan Pemerintah Nomor 45 Tahun 1990 tentang Perubahan Atas Peraturan Pemerintah Nomor 10 Tahun 1983 tentang Izin Pekawinan dan Perceraian Bagi Pegawai Negeri Sipil tentang pembagian gaji untuk mantan isteri dan anak. Pasal 8 Peraturan Pemerintah Nomor 45 Tahun 1990 tentang Perubahan Atas Peraturan Pemerintah Nomor 10 Tahun 1983 tentang Izin Pekawinan dan Perceraian Bagi Pegawai Negeri Sipil yang dimaksud pembagian gaji tersebut ialah sepertiga untuk Pegawai Negeri Sipil pria yang bersangkutan, sepertiga untuk bekas isteri, dan sepertiga untuk anak atau anak-anaknya. Jumlah gaji yang harus dibagikan menurut Pasal 8 huruf b ini adalah secara proporsional, sehingga gaji Pegawai Negeri Sipil yang ada dibagi habis untuk dirinya, istri, dan anak atau anak-anaknya (Syaifuddin, 2013). Tentunya dalam hal akan melibatkan bendahara instansi, yang kemudian bendahara instansi bukanlah pihak yang berperkara dalam perceraiannya. 
Dalam hal ini penulis mencoba untuk menjawab pelaksanaan putusan hakim dalam penetapan nafkah terhadap perceraian yang diajukan oleh Pegawai Negeri Sipil. Telah dijelaskan bahwa bagi Pegawai Negeri Sipil yang akan mengajukan perkara perceraian harus mendapatkan izin atasan, yang kemudian ketika Pegawai Negeri Sipil tidak meminta izin lalu melakukan perceraian maka akan dikualifikasikan sebagai melanggar hukum khusus perceraian sebagaimana menurut Pasal 15 ayat (1) Peraturan Pemerintah Nomor 45 Tahun 1990 tentang Perubahan Atas Peraturan Pemerintah Nomor 10 Tahun 1983 tentang Izin Pekawinan dan Perceraian Bagi Pegawai Negeri Sipil. Sedangkan ditekankan dalam Surat Edaran Kepala Badan Administrasi Kepegawaian Negara Nomor 48/SE/1990 tentang Petunjuk Pelaksanaan untuk Menyelesaikan Masalah Perceraian Pegawai Negeri Sipil bahwa: "Pegawai Negeri Sipil baik pria maupun wanita yang akan melakukan perceraian dan berkedudukan sebagai Tergugat, wajib memberitahukan secara tertulis adanya gugatan dari suami atau isterinya melalui saluran hirarki kepada pejabat yang mendapatkan surat keterangan, dalam waktu selambat-lambatnya 6 (enam) hari kerja ia menerima gugatan perceraian yang dibuat."

Adanya ketentuan tersebut tentunya setiap atasan instansi pemerintah telah mengetahui bahwa akan terjadinya proses perceraian yang akan dilakukan oleh Pegawai Negeri Sipil. Yang kemudian dalam prosesnya oleh Pejabat yang berwenang akan dicatatkan perceraiannya dalam setiap masing-masing lingkungan instansi pemerintahan. Sebagaimana dijelaskan dalam Pasal 19 Peraturan Pemerintah Nomor 45 Tahun 1990 tentang Perubahan Atas Peraturan Pemerintah Nomor 10 Tahun 1983 tentang Izin Pekawinan dan Perceraian Bagi Pegawai Negeri Sipil bunyinya "Setiap Pejabat atau Pejabat lain yang ditunjuk olehnya membuat dan memelihara catatan perkawinan dan perceraian Pegawai Negeri Sipil dalam lingkungannya masing-masing."

Tidak hanya dicatatkan dalam data induk kepegawaian masing-masing instansi tapi setiap instansi pemerintahan membuat salinan dan tembusan surat-surat perceraiannya meliputi izin atasan dan salinan putusan pengadilan untuk dibuatkan tembusan surat kepada Kepala Badan Administrasi Kepegawaian Negara, Pimpinan masing-masing Bank milik Negara, Badan Usaha milik Negara, Bank milik Daerah, Badan Usaha milik Daerah, serta Bupati Kepala Daerah Tingkat II, hal ini dijelaskan dalam Pasal 20 ayat (2) Peraturan Pemerintah Nomor 45 Tahun 1990 tentang Perubahan Atas Peraturan Pemerintah Nomor 10 Tahun 1983 tentang Izin Pekawinan dan Perceraian Bagi Pegawai Negeri Sipil,

Berdasarkan salinan dan tembusan surat-surat dimaksud dalam ayat (1) Kepala Badan Administrasi Kepegawaian Negara, Pimpinan masing-masing Bank milik Negara, Badan Usaha milik Negara, Bank milik Daerah, Badan Usaha milik Daerah, serta Bupati Kepala Daerah Tingkat II, membuat dan memelihara:

a. catatan perkawinan dan perceraian;

b. kartu isteri/suami “

Maka dengan keterangan beberapa pasal dan surat edaran Kepala BKN tersebut sebenarnya sangat mempermudah dalam pelaksanaan putusan Hakim. Dalam pertimbangan Majelis Hakim 
tentunya akan dicantumkan segala hal yang menjadi konsekuensi perceraian oleh Pegawai Negeri Sipil sebagaimana disebutkan dalam Pasal 8 Pemerintah Nomor 45 Tahun 1990 tentang Perubahan Atas Peraturan Pemerintah Nomor 10 Tahun 1983 tentang Izin Pekawinan dan Perceraian Bagi Pegawai Negeri Sipil yang dituangkan dalam amar putusan layaknya putusan perkara percerain yang dilakukan oleh masyarakat pada umumnya (non Pegawai Negeri Sipil).

Dikarenakan dalam pelaksanaannya Pemerintah Nomor 45 Tahun 1990 tentang Perubahan Atas Peraturan Pemerintah Nomor 10 Tahun 1983 tentang Izin Pekawinan dan Perceraian Bagi Pegawai Negeri Sipil mengatur bahwa kewajiban bagi Pegawai Negeri Sipil yang bercerai untuk melaporkan hasil putusan Pengadilan Agama, maka berdasarkan putusan tersebut oleh atasan instansi akan dijadikan pertimbangan untuk memerintahkan bendahara instansi menjalankan isi putusan Pengadilan Agama tersebut. Adapun ketika setelah putusan berkekuatan hukum tetap sedangkan Pemohon/Penggugat tidak melaporkan hasil putusan pengadilan kepada atasan dan diketahui telah bercerai dengan istri atau suaminya maka dianggap menolak melaksanakan pembagian gaji sebagaimana ketentuan yang imperatif falam Pasal 8 maka dijatuhi hukuman disiplin berat, dijelaskan dalam Peraturan Pemerintah Nomor 53 Tahun 2010.

Untuk pemberian gaji yang kemudian akan diberikan kepada mantan isteri dan anak atau anak-anaknya dalam hal ini ada dua cara yakni:

a. Bendaharawan gaji wajib menyerahkan secara langsung bagian gaji yang menjadi hak bekas isteri dan anak atau anak-anaknya sebagai akibat tanpa terlebih dahulu menunggu pengambilan gaji dari Pegawai Negeri Sipil bekas suami yang telah menceraikannya;

b. Bekas isteri dapat mengambil bagian gaji yang menjadi haknya secara langsung dari bendaharawan gaji, atau dengan surat kuasa, atau dapat meminta untuk dikirimkan kepadanya.

Sehingga pemerlakuan bagi Pegawai Negeri Sipil harus dilakukan secara khusus demi membantu terlaksananya Peraturan Pemerintah Nomor 45 Tahun 1990 tentang Perubahan Atas Peraturan Pemerintah Nomor 10 Tahun 1983 tentang Izin Pekawinan dan Perceraian Bagi Pegawai Negeri Sipil. Baik dari aparat penegak hukum di Pengadilan, Hakim, Panitera, Ketua Pengadilan dan instansi pemerintahan lainnya harus saling bersinergi agar putusan Pengadilan dapat dilaksanakan sebagaimana ketentuan yang berlaku. Oleh karena itu, seharusnya Pengadilan berhak mengirim salinan putusan kepada instansi terkait, agar sebagaimana Pasal 8 Peraturan Pemerintah Nomor 45 Tahun 1990 tentang Perubahan Atas Peraturan Pemerintah Nomor 10 Tahun 1983 tentang Izin Pekawinan dan Perceraian Bagi Pegawai Negeri Sipil dapat dilaksanakan dan diambil alih oleh pimpinan setiap instansi pemerintahan.

\section{KESIMPULAN}

Bagi Pegawai Negeri Sipil yang mengajukan perkara perceraian tentunya dalam hal ini ada konsekuensi hukum yang harus dilakukan, baik secara administratif dan kewajiban yang harus dilaksanakan oleh suami yang kedudukannya sebagai Pegawai Negeri Sipil. Adapun izin atasan tersebut diatur dalam Pasal 3 ayat (1) dan ayat (2) Peraturan Pemerintah Nomor 45 Tahun 1990 
tentang Perubahan Atas Peraturan Pemerintah Nomor 10 Tahun 1983 tentang Izin Pekawinan dan Perceraian Bagi Pegawai Negeri Sipil. Adapun kewajibannya diatur dalam Pasal 8 Peraturan Pemerintah Nomor 45 Tahun 1990 tentang Perubahan Atas Peraturan Pemerintah Nomor 10 Tahun 1983 tentang Izin Pekawinan dan Perceraian Bagi Pegawai Negeri Sipil. Kedudukan ex officio Hakim dalam memutus perkara perceraian dengan surat izin atasan bagi Pegawai Negeri Sipil. Dasarnya pada Pasal 41 huruf c Undang-Undang Nomor 1 Tahun 1974 tentang Perkawinan. Dalam perkara Cerai Talak dengan melihat ketentuan daripada Pasal 140 Kompilasi Hukum Islam akibat talak Maka apabila sedemikian rupa peraturan sudah diatur dalam Peraturan Pemerintah tersebut, Majelis Hakim secara ex officio dibenarkan memutus suatu perkara khususnya cerai talak dengan mempertimbangkan kedudukannya sebagai Pegawai Negeri Sipil dan konsekuensi hukumnya. Peraturan Pemerintah Nomor 45 Tahun 1990 tentang Perubahan Atas Peraturan Pemerintah Nomor 10 Tahun 1983 tentang Izin Pekawinan dan Perceraian Bagi Pegawai Negeri Sipil tentunya sebagai aturan khusus bagi Pegawai Negeri Sipil yang bercerai (lex spesialis derogate generalis). Adanya kewajiban bagi Pegawai Negeri Sipil yang telah bercerai untuk melaporkan kepada atasan dengan melampirkan putusan pengadilan dan akta cerai. Maka pelaksanaannya yang kemudian memerintahkan bendaharawan gaji untuk membagi gaji keseluruhannya kepada mantan isteri dan anak atau anak-anaknya adalah atasan yakni pejabat yang berwenang pada instansi tersebut.

\section{REFERENSI}

Al-Baihaqi, A. bin al-H. bin 'Ali bin M. A. B. (1994). Sunan al-Baihaqi al-Kubra. Makkah alMukarramah: Maktabah Dâr al-Baz.

Al-Daruquthni, 'Ali bin 'Umar Abu al-Hasan. (1966). Sunan al-Daruquthniy. Beirut: Dâr alMa'rifah.

Al-Malikiy, A. bin G. bin S. al-N. (n.d.). al-Fawakih al-Diwaniy. Beirut: Dâr al-Fikr.

Al-Nasa 'i, A. bin S. A. 'Abd al-R. (1986). Sunan al-Nasa iy-al-Mujtabi. Halab: Maktab alMathbu'at al-Islamiyyah.

Al-Thofina, M. I. N. (2018). Analisis Yuridis Terhadap Perceraian Pegawai Negeri Sipil Tanpa Izin Atasan (Studi Putusan Nomor: 3957/PDT.G/2016/PA.SDA). Universitas Islam Negeri Sunan Ampel.

Al-Zuhaili, W. (1998). Fiqh al-Islâmi wa Adillatuh. Beirut: Dar al-Fikr.

Anas, M. bin. (1994). Al-Mudawwamat al-Kubra. Beirut: Dar al - Fikr al - Arabi.

Annas, S. (2017). Masa Pembayaran Beban Nafkah Iddah dan Mut'ah dalam Perkara Cerai Talak (Sebuah Implementasi Hukum Acara di Pengadilan Agama). Al-Ahwal: Jurnal Hukum Keluarga Islam, 10(1), 1. https://doi.org/10.14421/ahwal.2017.10101

As'adi, E. (2012). Hukum Acara Perdata dalam Perspektif Mediasi di Indonesia. Yogyakarta: Graha Ilmu.

BKN. (2019). Statistik PNS.

Dahlan, A. A. (2009). Ensiklopedia Hukum Islam. Jakarta: Ictiar Baru Van Hoeven. 
Disemadi, H., Al-Fatih, S., \& Yusro, M. (2020). Indonesian Children Protection against Commercial Sexual Exploitation through Siri Marriage Practices in Maqashid Al-Shariah Perspective. Brawijaya Law Journal, 7(2), 195-212. https://doi.org/10.21776/ub.blj.2020.007.02.04

Fadri, K., Mukhlis, \& Yusrizal. (2020). Kewenangan Pengadilan Agama dan Pengadilan Tata Usaha Negara Terhadap Pembebanan Nafkah Anak Akibat Perceraian Pegawai Negeri Sipil. Suloh, 8(1), 48-69.

Fauzan, \& Noerfuady, E. (1997). Problemtika Penerapan Hak Ex Officio Hakim Dalam Penyelesaian Perkara Perceraian. Jakarta: Al-Hikmah \& DITBINBAPERA Islam.

Ghazaly, A. R. (2003). Fiqih Munakahat. Jakarta: Prenanda Media.

Hartini. (2009). Pengecualian terhadap Penerapan Asas Ultra Petitum Partium. Jakarta: Mimbar Hukum.

Irwansyah. (2020). Penelitian Hukum: Pilihan Metode \& Praktik Penulisan Artikel (A. Yunus, Ed.). Yogyakarta: Mirra Buana Media.

Kasany, A. B. bin M. al -. (2010). Al-badai al-Shana'i. Beirut: Dar al-Kutub al-Ilmiyah.

Mantili, R., \& Lubis, S. A. (2017). Pertimbangan Hakim Pengadilan Negeri terhadap Gugatan Perceraian yang tidak dapat Diterima (Niet Ontvankelijke Verklaard) dalam Praktik. ADHAPER, Jurnal Hukum Acara Perdata, 3(1), 111-134. https://doi.org/https://doi.org/10.36913/jhaper.v3i1.47

Mardani. (2012). Hadist Ahkam. Jakarta: Rajawali Press.

Matondang, A. (2014). Faktor-Faktor yang Mengakibatkan Percerian dalam Perkawinan. Jurnal Ilmu Pemerintahan Dan Sosial Politik UMA, 2(2), 141-150.

Nelli, J. (2017). Analisis Tentang Kewajiban Nafkah Keluarga dalam Pemberlakuan Harta Bersama. Al Istinbath, 2(1), 29-46. https://doi.org/http://dx.doi.org/10.29240/jhi.v2i1.195

Peter Mahmud Marzuki. (2017). Penelitian Hukum: Edisi Revisi (Cetakan ke). Jakarta: Kencana.

Purwadarminta, W. (2008). Kamus Besar Bahasa Indonesia. Jakarta: Balai Pustaka.

Puspa, Y. P. (1977). Kamus Hukum. Semarang: Aneka.

Qudamah, M. al - D. I. (1997). al- Mughny. Kuwait: Dar Alim al-Kutu.

Sabiq, S. (1998). Fiqh al - Sunnah. Kairo: al - Fath li al - A'lam al - Arabiy.

Saebani, B. A. (2001). Fikih Munakahat (Buku II). Bandung: Pustaka Amani.

Soeroso. (2010). Hukum Acara Perdata. Jakarta: Sinar Grafika.

Subekti. (1983). Pokok-Pokok Hukum Perdata. Jakarta: Intermasa.

Subekti, \& Tjitrosoedibjo, R. (1979). Kamus Hukum. Jakarta: Pradnya Paramita.

Syaifuddin, M. (2013). Hukum Perceraian. Jakarta: Sinar Grafika.

Syuhada. (2013). Analisis Tentang Konsekuensi Yuridis Harta Bersama Terhadap Kewajiban Suami Memberi Nafkah dalam KHI. Jurnal Tafaqquh, 1(1), 43-64.

Zuhaili, W. al -. (2008). Tafsir al-Munir. Beirut: Dar al-Fikr. 
Zuriah, N. (2009). Metodologi Penelitian Sosial dan Pendidikan. Jakarta: Bumi Aksara. 